\title{
Endothelial cells modulate eosinophil surface markers and mediator release
}

\author{
M-J. Dallaire, C. Ferland, N. Pagé, S. Lavigne, F. Davoine, M. Laviolette
}

Endothelial cells modulate eosinophil surface markers and mediator release. M-J. Dallaire, C. Ferland, N. Pagé, S. Lavigne, F. Davoine, M. Laviolette. (C)ERS Journals Ltd 2003. ABSTRACT: Migration from blood to tissue modulates eosinophil function, possibly through interactions with endothelial cells.

The effects of contact with and migration through endothelial cells on eosinophil expression of surface markers and release of leukotriene $C_{4}$ were evaluated.

A small proportion $(\mathbf{2 . 6 \%})$ of eosinophils spontaneously migrated through endothelial cell monolayers. Activation of endothelial cells by interleukin (IL)-4 or IL-1ß slightly increased this migration (to $12.4 \%$ ), which became much greater when a chemoattractant was placed in the lower chamber $(84.3 \%)$. However, the chemotactic effect was downregulated by pretreating endothelial cells with interferon gamma (IFN- $\gamma$; 63.1\%). At baseline, $5 \%$ of eosinophils expressed CD69; this increased to $30.7 \%$ in culture on untreated endothelial cells and to $50.9 \%$ on IL-1 $\beta$-pretreated endothelial cells. This effect was mediated through intercellular adhesion molecule-1/CD11b interaction. Eosinophil migration through endothelial cells further increased CD69 expression to $63.9 \%$ and also increased CD35 expression from 83.3 to $91.3 \%$. Upon stimulation, eosinophils that had migrated through endothelial cells produced more leukotriene $\mathrm{C}_{4}$ than control cells $\left(872.4\right.$ and $103.9 \mathrm{pg} \cdot \mathrm{mL}^{-1}$, respectively). Endothelial cell pretreatment with IL-4 or IL-1 $\beta$ further increased leukotriene $C_{4}$ release $(1,789.1$ and $2,895.1 \mathrm{pg} \cdot \mathrm{mL}^{-1}$, respectively), whereas pretreatment with IFN- $\gamma$ decreased it $\left(293.7 \mathrm{pg} \cdot \mathrm{mL}^{-1}\right)$.

These data show that in vitro interactions with endothelial cells upregulate eosinophil membrane receptor expression and mediator release and that these effects are differently modulated by T-helper cell type 1 and 2 cytokines. These eosinophil modulations may play an important role in asthma pathogenesis.

Eur Respir J 2003; 21: 918-924.
Unité de Recherche en Pneumologie, Centre de Recherche de 1'Hôpital Laval, Institut Universitaire de Cardiologie et de Pneumologie de 1'Université Laval, Quebec, Canada.

Correspondence: M. Laviolette

Hôpital Laval

2725 Chemin Sainte-Foy

Québec, PQ

G1V 4G5

Canada

Fax: 14186564762

E-mail: Michel.Laviolette@med.ulaval.ca

Keywords: CD35

CD69

human umbilical vein endothelial cells

leukotriene $\mathrm{C} 4$

transmigration

Received: November 72002

Accepted after revision: January 212003

This study was supported by the Canadian Institutes of Health Research, Ottawa, Canada (MOP-49534).
Eosinophils are recruited to tissue in various pathological conditions [1]. In asthma, eosinophils infiltrate the bronchial mucosa [2] and their counts in blood, sputum and bronchial mucosa correlate with indices of disease severity [3-4]. Blood eosinophils are thought to circulate in a quiescent state until they migrate into the tissue [5]. In healthy mucosa, eosinophils account for a small proportion of the cells, making it almost impossible to evaluate their activation status. In eosinophilic diseases in which their numbers increase, tissue eosinophils show increased expression of complement and immunoglobulin (Ig)G receptors compared to their blood counterparts $[1,5]$. They also express intercellular adhesion molecule (ICAM)-1, human leukocyte antigen (HLA)-DR and CD69, which are barely or not detectable on blood eosinophils [6-9]. Tissue eosinophils show increased release of superoxide anion and leukotriene (LT)C $\mathrm{C}_{4}$ compared to blood eosinophils [10, 11]. Lung lavage eosinophils, obtained after segmental bronchoprovocation, show an increase in membrane receptors, adhesion, survival and generation of superoxide anions, which was not achieved by incubation of blood eosinophils with interleukin (IL)-5 and granulocyte macrophage-colony stimulating factor (GM-CSF) [12-14]. These observations suggest that passage into tissue activates eosinophils, increasing their pro-inflammatory potential. The factors involved in this phenomenon have yet to be fully determined.
During their recruitment to tissue eosinophils pass through the endothelium. This is a complex process [1, 14, 15] and interactions with endothelial cells have been shown to modulate certain eosinophil functions [16]. Activation of endothelium is an important step in inflammatory processes and occurs in disease models, including those for allergic diseases [17]. Endothelial cells exposed to cytokines such as IL-1 $\beta$, IL-4 and tumour necrosis factor- $\alpha$ increase their expression of ICAM-1 and vascular cell adhesion molecule (VCAM)-1 [18, 19], which serve as ligands for eosinophil integrins. Consequently, cytokines may modulate the transendothelial migration of eosinophils and amplify endothelial cell-induced changes in eosinophil functions [19, 20].

In order to further clarify the role of endothelial cells in the modulation of eosinophils during their migration to tissue, the effects of eosinophil migration through a human umbilical vein endothelial cell monolayer on expression of cell-surface markers and liberation of $\mathrm{LTC}_{4}$, a powerful bronchoconstrictor and pro-inflammatory mediator, were evaluated. It was found that expression of CD69, an early marker of activation, and of $\mathrm{CD} 35$, a receptor for complement proteins, and $\mathrm{LTC}_{4}$ release were modulated by endothelial cells and that treatment of endothelial cells with T-helper cell type 1 and 2 cytokines differently modified their effect on eosinophils. 


\section{Materials and methods}

\section{Reagents}

Platelet-activating factor (PAF), activated complement fraction 5a (C5a) and bovine serum albumin (BSA) were purchased from Sigma Chemical Co. (St Louis, MO, USA). Kits for $\mathrm{LTC}_{4}$ determination and 5-oxo-6, 8, 11, 14-eicosatetraenoic acid (5-oxo-ETE) were obtained from Cayman Chemical (Ann Arbor, MI, USA). Purified monoclonal mouse antibody IgG1 $\kappa$ and $\mathrm{IgG} 2 \mathrm{~b}$ (isotypic control), purified human antiCD4, anti-CD16, anti-CD28, anti-CD86, anti-CD35, anti-CD69 and anti-HLA-DR and phycoerythrin-conjugated polyclonal antimouse antibodies were purchased from BD Biosciences (Mississauga, ON, Canada). In specific experiments, fluorescein isothiocyanate (FITC)-conjugated anti-CD69 antibodies were used. Monoclonal mouse antihuman CD16 antibodies were purchased from Miltenyi Biotec (Auburn, CA, USA) and human recombinant IL-1 $\beta$, IL-4 and interferon gamma (IFN$\gamma$ ) from Peprotech, Inc. (Rocky Hill, NJ, USA). Monoclonal mouse antihuman CD11b antibody (clone bear 1) was obtained from Beckman Coulter (Mississauga, ON, Canada) and fibronectin was from Roche Diagnostics (Laval, QC, Canada). Anti-ICAM-1 antibody (clone HA58) was purchased from BD Biosciences. Human umbilical vein endothelial cells cryopreserved from a single donor in primary culture were purchased from Clonetics (San Diego, CA, USA).

\section{Subject selection}

Seven normal subjects (two male/five female, median age 31 yrs (range 18-55 yrs)) without a history of allergy or asthma and 10 asthmatics (five male/five female, median age 23.5 yrs (range 19-35 yrs)) meeting the criteria of the American Thoracic Society for the diagnosis of asthma were recruited for the study [21]. The asthmatic subjects had a morning prebronchodilator forced expiratory volume in one second (FEV1) of $>85 \%$ of the predicted value and required only a short-acting $\beta_{2}$-agonist on demand on less than four occasions per week. The inclusion criteria included stable treatment for $>3$ months, no inhaled steroids over the 3 months preceding the study, no use of other drugs and no disease other than asthma. Approval for the study was obtained from the local ethics committee and all subjects signed an informed consent form. FEV1 and provocative concentration of methacholine causing a $20 \%$ fall in FEV1 (PC20) were measured in the morning, $\geqslant 8 \mathrm{~h}$ after any $\beta_{2-}$ agonist inhalation. Median FEV1 for normal and asthmatic subjects were 98.5 (91-110) and 96 (86-102)\% pred, respectively ( $\mathrm{p}=0.03)$, and geometric mean PC20 were $43.9 \pm 19.7$ and $1.1 \pm 0.9 \mathrm{mg} \cdot \mathrm{mL}^{-1}$, respectively $(\mathrm{p}=0.006$, Wilcoxon rank-sum test). Subjects underwent blood sampling early in the morning. Mean blood eosinophil counts were $0.2 \times 10^{9}$ and $0.3 \times 10^{9}$ cells $\cdot \mathrm{L}^{-1}$ for normal and asthmatic subjects, respectively.

\section{Blood eosinophil purification}

Eosinophils were purified as previously described [22]. They were separated from neutrophils by negative selection using a magnetic cell sorter. An aliquot of the cell suspension was used to determine cell number (haemocytometer) and viability (trypan blue exclusion; Sigma Chemical Co.) and differential cell counts (Diff-Quik; Dade Diagnostics, Aguada, PR, USA). The purity of the eosinophil preparations used in this study was $>98 \%$ and the contaminating cells were neutrophils and/ or lymphocytes. Eosinophil viability was always $>99 \%$.

\section{Endothelial cell culture}

Endothelial cells were grown in endothelial growth medium supplemented with human recombinant epidermal growth factor, human fibroblast growth factor, vascular endothelial growth factor, ascorbic acid, long- $\mathrm{R}^{\mathfrak{3}}$ insulin-like growth factor-I, heparin, hydrocortisone, gentamicin and amphotericin B (Clonetics) and 10\% foetal bovine serum (FBS) (Invitrogen Canada, Burlington, ON, Canada) in a 5\% carbon dioxide $\left(\mathrm{CO}_{2}\right)$ atmosphere at $37^{\circ} \mathrm{C}$. When $\sim 80 \%$ confluent, cells were harvested, resuspended in fresh culture medium and seeded at a density of $2 \times 10^{5}$ cells $\cdot 500 \mu \mathrm{L}^{-1}$ on cell culture inserts (12-mm diameter polycarbonate membrane with $3.0-\mu \mathrm{m}$ pores; BD Biosciences Labware, Mississauga, ON, Canada). The inserts were placed in 24-well culture plates (BD Biosciences Labware), culture medium without FBS $(500 \mu \mathrm{L})$ was placed in the lower chamber to inhibit formation of an endothelial cell bilayer [23] and the cells cultured for 5 days. Endothelial cell monolayers were confirmed as being at confluence by toluidine blue staining on control inserts. All experiments were carried out on passage 4 cells. In specific experiments, endothelial cells were cultured on the bottom of 24-well culture plates.

\section{Incubation of eosinophils with endothelial cells and transendothelial migration}

Confluent endothelial cell monolayers were treated with IFN- $\gamma\left(1,000 \mathrm{U} \cdot \mathrm{mL}^{-1}\right)$ for $72 \mathrm{~h}, \mathrm{IL}-4\left(100 \mathrm{U} \cdot \mathrm{mL}^{-1}\right)$ for $24 \mathrm{~h}$ or IL-1 $\beta\left(50 \mathrm{U} \cdot \mathrm{mL}^{-1}\right)$ for $4 \mathrm{~h}$ in a $5 \% \mathrm{CO}_{2}$ atmosphere at $37^{\circ} \mathrm{C}$. These cytokines were added to the upper compartment of the wells. Times of incubation and cytokine concentrations were chosen based on the results of previous studies [24-27]. Thereafter, the upper and lower compartments of the wells were washed three times with Hank's balanced salt solution (HBSS) $\left(37^{\circ} \mathrm{C}\right)$. Eosinophils $\left(1 \times 10^{6}\right.$ cells $\cdot \mathrm{mL}^{-1}$ in Roswell Park Memorial Institute 1640 containing 10\% FBS and $1 \%$ penicillin/streptomycin) were laid in inserts coated or not with endothelial cells. A potent eosinophil chemoattractant, 5-oxo-ETE $(1 \mu \mathrm{M})$, was added to the lower chamber of some wells to induce migration [22]. After a 4-h incubation, eosinophils recovered from the upper chambers served to evaluate the effect of contact with endothelial cells and cells that had migrated through endothelial cell-coated inserts under the action of 5-oxo-ETE served to evaluate the effect of transendothelial migration. In these two sets of experiments, inserts without endothelial cells served as controls. In specific experiments, to further evaluate the effects of endothelial cell contact in the presence or absence of 5-oxo-ETE and to prevent migration through endothelial cells, eosinophils were incubated in 24-well culture plates coated or not with endothelial cells. Moreover, in order to evaluate the role of ICAM-1/CD11b ligation in eosinophil/endothelial cell interactions, an anti-ICAM-1 antibody $\left(20 \mu \mathrm{g} \cdot \mathrm{mL}^{-1}\right)$ was added to the incubation medium. The migration rate is presented as the percentage of cells in the upper chamber that migrate into the lower chamber. At the end of incubations, the viability of the eosinophils was always $>98 \%$.

\section{Incubation on fibronectin- or anti-CD11b antibody- coated plates}

In order to study the effect of $\mathrm{CD} 11 \mathrm{~b}$ and very late activation antigen-4 (VLA-4) ligation on eosinophil CD69 expression, 96-well culture plates (Nunc-Immuno Plate Maxisorp Surface; VWR International, Montreal, QC, Canada) were incubated with either $100 \mu \mathrm{L}$ fibronectin $\left(20 \mu \mathrm{g} \cdot \mathrm{mL}^{-1}\right)$, 
$100 \mu \mathrm{L}$ anti-CD11b monoclonal antibody $\left(20 \mu \mathrm{g} \cdot \mathrm{mL}^{-1}\right)$, both fibronectin and anti-CD11b antibody, or $100 \mu \mathrm{L}$ HBSS (control) overnight at $4^{\circ} \mathrm{C}$. At the end of this incubation, the wells were washed twice with HBSS and nonspecific protein binding was blocked by addition of $100 \mu \mathrm{L}$ HBSS containing $1 \%$ BSA for $1 \mathrm{~h}$ at $37^{\circ} \mathrm{C}$. Before use, the coated wells were washed with HBSS and eosinophils $\left(1 \times 10^{5}\right.$ cells. $100 \mu \mathrm{L}^{-1}$ ) were added to wells and incubated for $4 \mathrm{~h}$ at $37^{\circ} \mathrm{C}$. Cells were then harvested and stained with FITC-conjugated antihuman CD69 as described below.

\section{Cell-surface marker detection}

Eosinophils were labelled $\left(2 \times 10^{5}\right.$ cells $\cdot 100 \mu \mathrm{L}^{-1}$ for $30 \mathrm{~min}$ at $\left.4^{\circ} \mathrm{C}\right)$ with specific antibodies $\left(1 \mu \mathrm{g} \cdot \mathrm{mL}^{-1}\right)$ directed against CD4, CD16, CD28, CD35, CD69, CD86 and HLA-DR or with their respective isotypic control, as previously described $[28,29]$. After incubation, cells were washed with HBSS containing 1\% BSA and fixed in 4\% paraformaldehyde (10 min at $4{ }^{\circ} \mathrm{C}$ ). Phycoerythrin-conjugated antimouse secondary antibody $\left(1 \mu \mathrm{g} \cdot \mathrm{mL}^{-1}\right)$ was then added (for $30 \mathrm{~min}$ at $4^{\circ} \mathrm{C}$ ). In experiments with incubation on fibronectin- or anti-CD11b antibody-coated plates, FITC-conjugated anti-CD69 antibodies were used. Finally, eosinophils were washed, suspended in HBSS containing $1 \%$ BSA, kept at $4{ }^{\circ} \mathrm{C}$ and immediately subjected to cytometric analysis using an EPICS $\AA$ ELITE ESP flow cytometer (Beckman-Coulter, Miami, FL, USA). Mean fluorescence (MF) was measured on a logarithmic scale $[28,29]$ and the percentage of cells expressing a particular marker determined by counting the number of cells showing greater fluorescence activity than $\geqslant 96 \%$ of negative controls.

\section{Leukotriene $\mathrm{C}_{4}$ assay}

Eosinophils $\left(1 \times 10^{6}\right.$ cells $\cdot \mathrm{mL}^{-1}$ in $\left.\mathrm{HBSS} / \mathrm{CaCl}_{2}(1.6 \mathrm{mM})\right)$ were incubated with PAF $(1 \mu \mathrm{M})$ for $10 \mathrm{~min}$ at $37^{\circ} \mathrm{C}$ under $5 \% \mathrm{CO}_{2}$ and thereafter with $\mathrm{C} 5 \mathrm{a}(10 \mathrm{nM})$ under the same conditions. Tubes were then put on ice for 5 min to stop the reaction. Cells were centrifuged and $\mathrm{LTC}_{4}$ measured in the supernatants by quantitative enzyme immunoassay according to the manufacturer's recommendations.

\section{Statistical analyses}

Mediator and cell-surface marker expression data were analysed using a crossed-nested design (analysis of variance). Data are presented as mean \pm SEM and results were considered significant when $\mathrm{p}$ was $<0.05$. There was no difference between the eosinophils of normal and asthmatic subjects for all measured parameters under all tested conditions. Their data were, therefore, pooled together for analysis and presentation.

\section{Results}

\section{Migration through endothelial cells}

Spontaneous eosinophil migration through uncoated inserts, untreated endothelial cells and IFN- $\gamma$-pretreated endothelial cells was $1.4 \pm 0.2,2.6 \pm 0.3$ and $2.1 \pm 0.4 \%$, respectively (fig. 1 ). Pretreatment of endothelial cells with IL- 4 or IL-1 $\beta$ increased eosinophil migration to $11.5 \pm 0.9$ and $12.4 \pm 0.8 \%$, respectively $(\mathrm{p}=0.0001)$. Addition of 5-oxo-ETE to the lower chambers dramatically stimulated eosinophil migration through endothelial cells $(84.3 \pm 1.0 \% ; \mathrm{p}=0.0001)$. Pretreatment of endothelial cells with IFN- $\gamma$ decreased the effect of 5-oxo-ETE on eosinophil

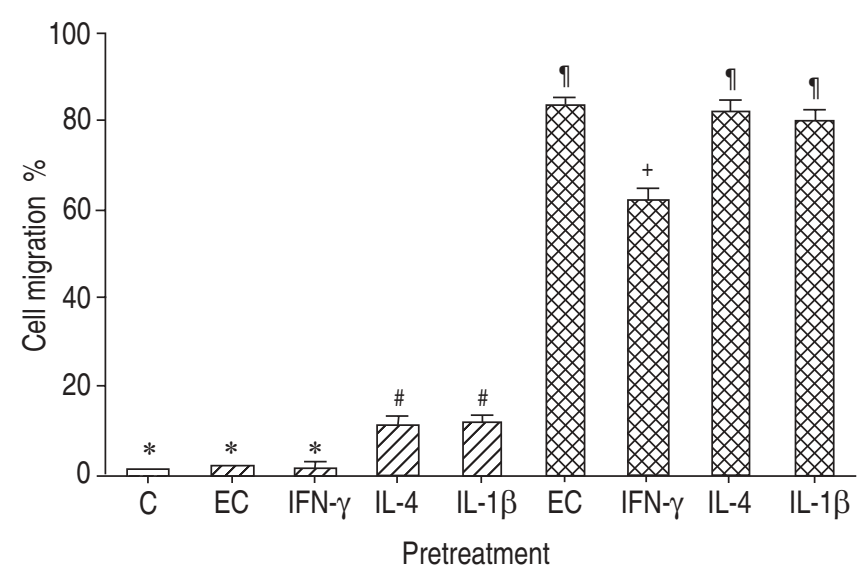

Fig. 1. - Migration of eosinophils through endothelial cell monolayers. Eosinophils were laid on cell culture inserts coated $(\mathbb{Z} ; \mathbf{E})$ or not $(\square)$ with endothelial cells. Data are presented as mean \pm SEM. The eosinophils barely migrated through uncoated inserts (C) and inserts coated with untreated endothelial cells (EC). Pretreatment of endothelial cells with interleukin (IL)- 4 or IL-1 $\beta$ but not interferon gamma (IFN- $\gamma$ ) increased eosinophil migration. When 5-oxo-6, 8, 11, 14-eicosatetraenoic acid was added to the lower chambers $(\mathbf{D})$, most eosinophils migrated through inserts coated with endothelial cells, but this effect decreased with IFN- $\gamma$-pretreatment of endothelial cells. ${ }^{*},{ }^{\#},{ }^{\uparrow},{ }^{+}: \mathrm{p}=0.001$ versus each other ( $\mathrm{n}=17$ for each).

migration $(63.1 \pm 1.3 \% ; \mathrm{p}=0.0001)$. In contrast, pretreatment of endothelial cells with IL-4 or IL-1 $\beta$ did not modify 5-oxoETE-induced migration ( $82.8 \pm 1.3$ and $81.8 \pm 2.0 \%$, respectively).

\section{Eosinophil surface marker expression}

Among eosinophils incubated on uncoated inserts and recovered from the upper chambers, the percentage of CD69positive cells was $5.0 \pm 2.2 \%(0.06 \pm 0.02 \mathrm{MF})$ and increased to $30.7 \pm 8.4 \%(0.34 \pm 0.11 \mathrm{MF})$ on inserts coated with untreated endothelial cells $(p<0.0001)$ (fig. 2a). Contact of eosinophils with endothelial cells in culture plates in the presence of 5-oxo-ETE induced similar CD69 expression $(27.2 \pm 6.2 \%$; $0.2 \pm 0.04 \mathrm{MF})$ to incubation on endothelial cells alone. Pretreatment of endothelial cells with IFN- $\gamma$ or IL-4 did not modify eosinophil expression of CD69 (36.3 $\pm 7.6 \%(0.35 \pm$ $0.06 \mathrm{MF})$ and $45.4 \pm 7.3 \%(0.43 \pm 0.05 \mathrm{MF})$, respectively). However, pretreatment of endothelial cells with IL-1 $\beta$ increased CD69-positive eosinophil percentages $(50.9 \pm 10.8 \%$; $0.58 \pm$ $0.14 \mathrm{MF})(\mathrm{p}<0.0001)$. Compared to cells incubated on endothelial cells, eosinophils of the lower chambers that had migrated through endothelial cells under the action of 5-oxo-ETE showed a further increase in CD69 expression $(63.9 \pm 7.0 \% ; 0.88 \pm 0.18 \mathrm{MF} ; \mathrm{p}=0.004)$ (fig. $2 \mathrm{~b}$ ). Migration of eosinophils through cytokine-pretreated endothelial cells did not further modify CD69 expression compared to migration across untreated endothelial cells.

The effect of CD11b and VLA-4 ligation on eosinophil CD69 expression is presented in figure 3. Eosinophils incubated on fibronectin showed low expression of CD69 $(6.2 \pm 1.5 \%)$, similar to control wells $(4.2 \pm 1.4 \%)$. In contrast, cells incubated on anti-CD11b antibody-coated wells exhibited increased expression of CD69 (27 $\pm 6 \%$; $=0.007 ; \mathrm{n}=6)$. Addition of fibronectin did not modify this expression $(26.8 \pm 11.5 \%)$. These values were similar to those observed with eosinophils incubated on untreated endothelial cells (fig. 2a). Furthermore, in two experiments eosinophils were incubated on endothelial cells in the presence of an antiICAM-1 antibody. This antibody decreased endothelial cellinduced CD69 expression from 36.6 to $2.4 \%$.

The expression of CD35 in eosinophils incubated in uncoated 

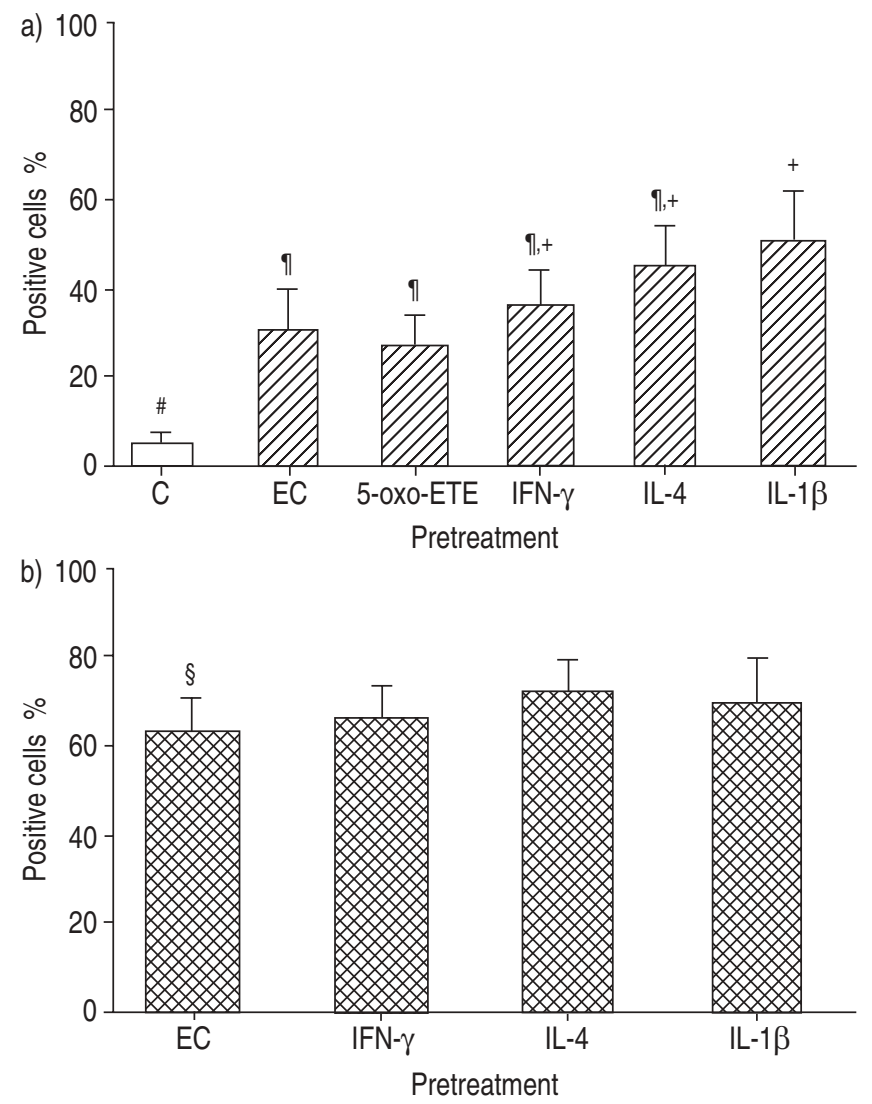

Fig. 2.-Expression of CD69 receptors on a) eosinophils incubated on inserts or culture plates coated $(\mathbb{Z})$ or not $(\square)$ with endothelial cells and b) cells that migrated through inserts coated with endothelial cells under the effect of 5-oxo-6, 8, 11, 14eicosatetraenoic acid (5-oxo-ETE) (- Data are presented as mean \pm SEM. a) Eosinophil CD69 expression increased in contact with endothelial cells (EC) compared to cells that have not been in contact with endothelial cells (C). Pretreatment of endothelial cells with interleukin (IL)-1 $\beta$, but not IL-4 or interferon gamma (IFN- $\gamma$ ), further increased eosinophil CD69 expression. b) Migration through endothelial cells under the effect of 5-oxo-ETE doubled the number of CD69-positive eosinophils compared with nonmigrated cells incubated on endothelial cells in the presence of 5-oxo-ETE. \#,,+ : $\mathrm{p}<0.0001$ versus each other; \$: $\mathrm{p}=0.0037$ versus nonmigrated cells $(\mathrm{n}=13)$.

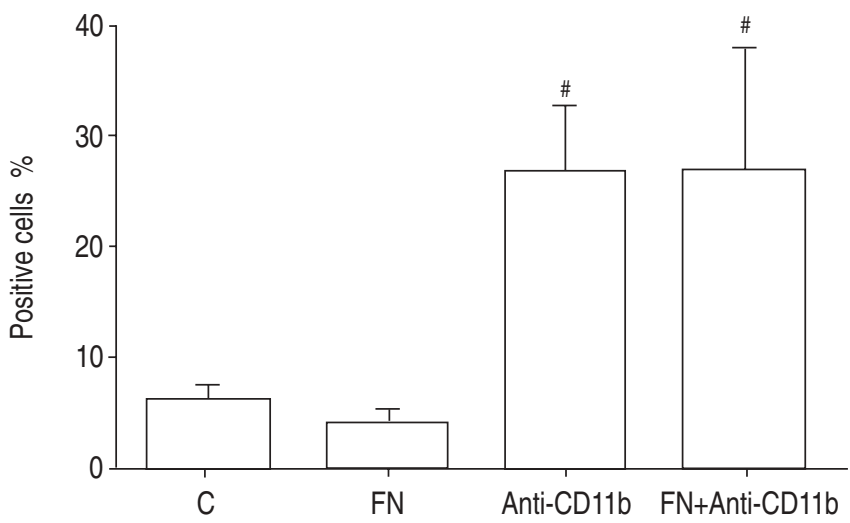

Fig. 3. - Expression of CD69 receptors of eosinophils incubated on fibronectin (FN)- and anti-CD11b antibody-coated wells. Data are presented as mean \pm SEM. Compared to control (C) and FN-coated wells, incubation of cells on anti-CD11b antibody-coated wells induced an increase in CD69-positive cells. ${ }^{\#}: \mathrm{p}<0.007$ versus control and FNcoated wells $(n=6)$. inserts $(83.3 \pm 4.5 \% ; 1.2 \pm 0.1 \mathrm{MF})$, inserts coated with endothelial cells $(85.5 \pm 2.6 \% ; 1.4 \pm 0.2 \mathrm{MF})$ or on endothelial cells in the presence of 5 -oxo-ETE $(85.5 \pm 3.8 \% ; 1.8 \pm 0.3 \mathrm{MF})$ were similar (fig. 4a). Treatment of endothelial cells with cytokines did not modify eosinophil CD35 expression: IFN- $\gamma$ 87.9 $\pm 1.1 \%$, IL-4 90.1 $\pm 1.4 \%$, and IL- $1 \beta 89.5 \pm 2.3 \%(\mathrm{p}=0.38)$. Migration of eosinophils through endothelial cells under the action of 5-oxo-ETE significantly increased CD 35 expression $(91.3 \pm 3.2 \%$; $1.9 \pm 0.3 \mathrm{MF})$ compared to cells incubated in inserts coated with endothelial cells and that had not migrated $(\mathrm{p}=0.0013)$ (fig. 4b). Cytokine pretreatment of endothelial cells did not modify the CD35 expression of migrated eosinophils.

Purified blood eosinophil expression of CD4, CD16, CD28,

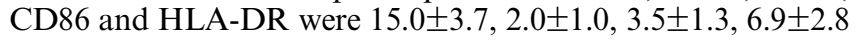
and $1.5 \pm 0.3 \%$, respectively $(\mathrm{n}=4-8)$. Contact with and migration through endothelial cell monolayers did not modify eosinophil expression of these surface markers (data not shown).

\section{Leukotriene $C_{4}$ release}

Compared to eosinophils recovered from the upper chambers, cells of lower chambers that migrated through endothelial
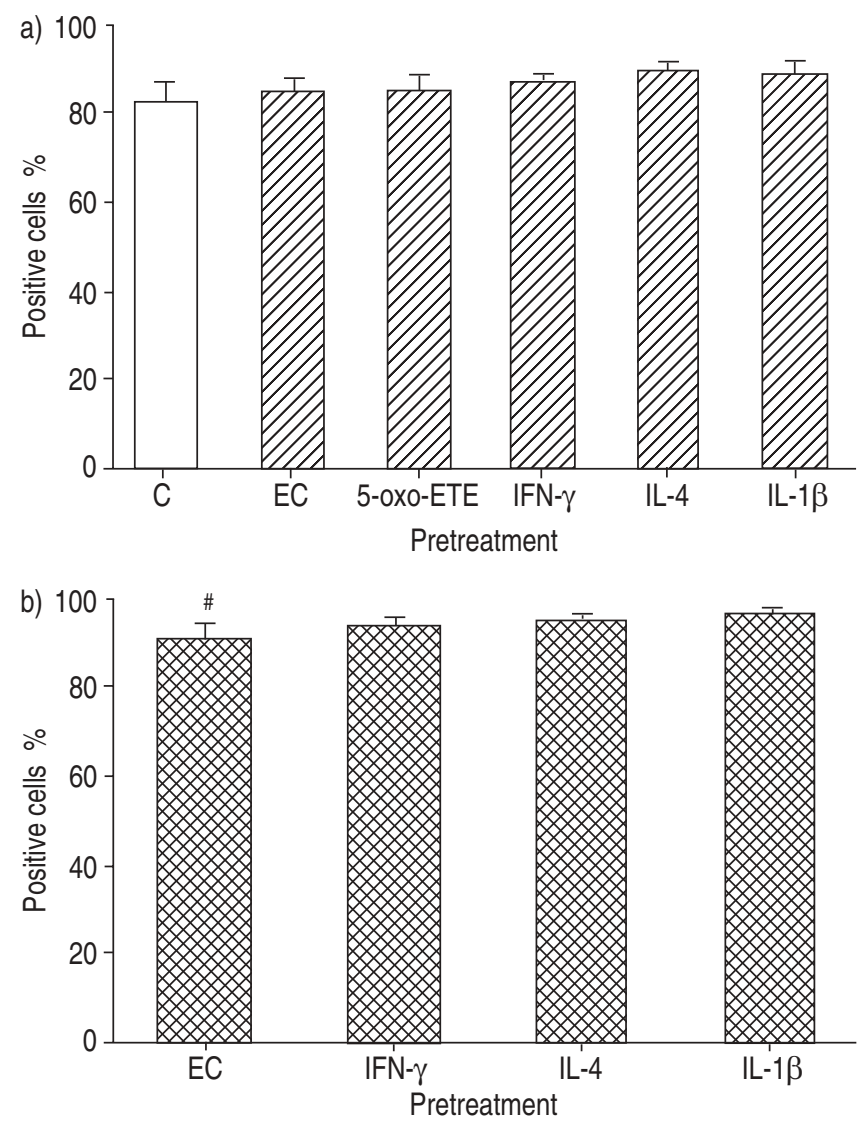

Fig. 4. - Expression of CD35 receptors on a) eosinophils incubated on inserts or culture plates coated $(\mathbb{Z})$ or not $(\square)$ with endothelial cells and b) cells that migrated through inserts coated with endothelial cells (EC) under the effect of 5-oxo-6, 8, 11, 14-eicosatetraenoic acid (5-oxo-ETE) (- Data are presented as mean \pm SEM. a) CD35 expression of eosinophils incubated on inserts coated or not with endothelial cells were similar $(n=8)$. b) Migration of eosinophils through inserts coated with endothelial cells under the effect of 5-oxo-ETE significantly increased CD35 expression compared to nonmigrated cells incubated on endothelial cells in the presence of 5-oxo-ETE. EC: untreated endothelial cells. ${ }^{\#}: \mathrm{p}=0.0013$ versus nonmigrated cells $(\mathrm{n}=13)$. C: eosinophils incubated on uncoated cells; IFN- $\gamma$ : interferon gamma; IL: interleukin. 


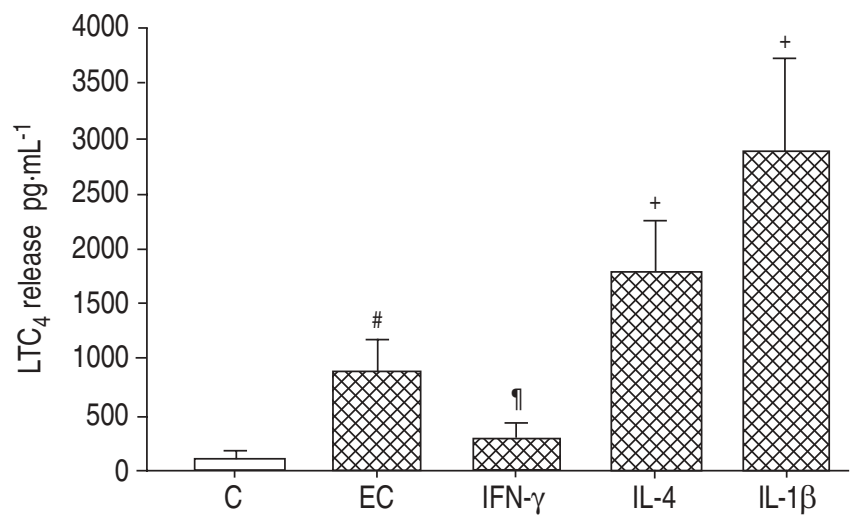

Fig. 5.- Release of leukotriene (LT) $\mathrm{C}_{4}$ by eosinophils under migration conditions. Data are presented as mean \pm SEM. Release of $\mathrm{LTC}_{4}$ by eosinophils that had migrated across inserts coated with endothelial cells (EC) under the effect of 5-oxo-6, 8, 11, 14-eicosatetraenoic acid ( was increased compared to eosinophils incubated on uncoated inserts $(\mathrm{C} ; \square)(\mathrm{p}=0.0055)$. Eosinophils that migrated through interleukin (IL)-4- or IL-1 $\beta$-pretreated endothelial cells released more $\mathrm{LTC}_{4}$ than eosinophils that migrated through untreated or interferon gamma (IFN- $\gamma$ )-pretreated endothelial cells. \#, ', ${ }^{+}: \mathrm{p}<0.0006$ versus each other $(n=10)$.

cells under the action of 5-oxo-ETE released more than eight times more $\mathrm{LTC}_{4}\left(103.9 \pm 30.2\right.$ and $872.4 \pm 292.5 \mathrm{pg} \cdot \mathrm{mL}^{-1}$, respectively; $\mathrm{p}=0.0055$ ) (fig. 5). Migration through IFN- $\gamma-$ pretreated endothelial cells decreased eosinophil $\mathrm{LTC}_{4}$ release $\left(293.7 \pm 116.9 \mathrm{pg} \cdot \mathrm{mL}^{-1} ; \mathrm{p}=0.0006\right)$. In contrast, migration through IL-4- and IL-1 $\beta$-treated endothelial cells further increased eosinophil $\mathrm{LTC}_{4}$ release $(1,789.1 \pm 457.3$ and $2,895.1 \pm 831.4 \mathrm{pg}$. $\mathrm{mL}^{-1}$, respectively; $\left.\mathrm{p}=0.0006\right)$. Eosinophils incubated in endothelial cell-coated and uncoated culture plates released similar amounts of $\mathrm{LTC}_{4}\left(32.4 \pm 12.7\right.$ and $82.9 \pm 28.2 \mathrm{pg} \cdot \mathrm{mL}^{-1}$, respectively; $\mathrm{p}=0.2, \mathrm{n}=6$ ). Moreover, under these conditions, addition of 5-oxo-ETE did not amplify the PAF/C5a-induced $\mathrm{LTC}_{4}$ release $(32.4 \pm 12.4 ; n=3)$.

\section{Discussion}

Eosinophil emigration from blood to tissue and migration through endothelium may contribute to the observed activation status of tissue eosinophils compared to their blood counterparts. This study shows that in vitro contact with endothelial cells increases eosinophil CD69 expression and that eosinophil migration through an endothelial cell monolayer further increases CD69 expression and also augments CD35 expression and $\mathrm{LTC}_{4}$ release. Moreover, the endothelial cell effects on eosinophils are modulated by cytokines, IL$1 \beta$ or IL-4 amplifying them and IFN- $\gamma$ decreasing them.

In the present study, endothelial cell pretreatment with IL-4 or IL- $1 \beta$ but not IFN- $\gamma$ facilitated the passage of eosinophils across endothelial cell monolayers. Since IL-4 and IL-1 $\beta$ upregulate ICAM-1 and VCAM-1 on endothelial cells [30, 31], these ligands may increase adhesion of eosinophils to endothelial cells via Mac-1 (a $\beta_{2}$ integrin) and VLA-4, respectively, and, consequently, may promote eosinophil migration.

5-oxo-ETE, a potent chemoattractant [32], promoted the migration of most of the eosinophils. IFN- $\gamma$ partially inhibits 5-oxo-ETE-induced eosinophil migration. The mechanism of this inhibition remains undefined. IFN- $\gamma$ has no known effect on the expression of adherence molecules such as VCAM-1 but increases the expression of ICAM-1 on airway epithelium [33].

Induction of CD69 expression on eosinophils has been reported as an indication of eosinophil activation [34]. The function of CD69 on eosinophils and other cell types is not entirely understood, although engagement of this marker leads to eosinophil apoptosis in vitro and cytokine release in other cell types [35]. CD69 may be a coreceptor for eosinophil activation, or, as for platelets and monocytes, facilitate mediator release or degranulation [9, 36, 37]. CD69 is barely detectable on freshly isolated eosinophils but is rapidly expressed after stimulation with numerous cytokines [9, 38-40]. CD69 is also present on bronchoalveolar lavage eosinophils [8, 9, 34]. The present data and the recent report of YАмАмото et al. [16] show that CD69 expression is increased by contact with and further increased after migration through endothelial cells. The induction of CD69 expression is also observed on eosinophils incubated with antibodies directed against CD11b and inhibited by an anti-ICAM-1 antibody, suggesting that binding of eosinophils to endothelial cells via ICAM-1/ $\beta_{2}$ integrin interaction is probably involved in endothelial cellmediated eosinophil activation. The greater expression of CD69 on migrated eosinophils is probably due to the effect of migration through the endothelial cell monolayer, given that CD69 expression on eosinophils cocultured with endothelial cells in the presence of 5-oxo-ETE was not increased compared to that on eosinophils in contact with endothelial cells. YAмАмото et al. [16] showed that migration across IL-1 $\beta$ pretreated endothelial cells stimulated eosinophil expression of CD69, CD54 and HLA-DR. The present study failed to show upregulation of CD69 and HLA-DR expression on eosinophils that had migrated across IL-1 $\beta$-treated endothelial cells compared to those that had migrated through unstimulated endothelial cells. One possible explanation for this discrepancy is the different eosinophil populations studied. YАмАмото et al. [16] analysed a small population of eosinophils ( $<15 \%$ of total eosinophils placed on the endothelial cell monolayer) that migrated spontaneously through IL-1 $\beta$-pretreated endothelial cells, whereas the present study analysed eosinophils that migrated through endothelial cells under the action of 5-oxo-ETE ( $>80 \%$ of total eosinophils). Moreover, YАмАмото et al. [16] measured MF on a linear scale, which greatly increases the sensitivity but also significantly decreases the specificity of measurements.

In the present study, CD35 was highly expressed on blood eosinophils. As shown by WALKER et al. [27], this expression was not modified by contact with, but increased slightly after migration through, endothelial cells. Complement receptors such as CD35 are known to play a role in the activation and adhesion of neutrophils and eosinophils, and, during asthmatic reaction, expression of these receptors is elevated on circulating granulocytes [41]. In contrast, other receptors, CD4, CD16, CD28, CD86 and HLA-DR, were barely expressed by blood eosinophils and their expression was not upregulated by migration through endothelial cells. These receptors are involved in interactions of eosinophils with mediators and other cells and are upregulated on tissue eosinophils [42]. The present results suggest that eosinophil migration through endothelial cells is not involved in this upregulation.

The present study shows that passage of eosinophils through endothelial cells modulates $\mathrm{LTC}_{4}$ release. MUNOZ et al. [43] reported that incubation on IL-1 $\beta$-treated endothelial cells but not endothelial cells alone augmented $\mathrm{LTC}_{4}$ release from stimulated eosinophils and that this augmentation was related to the process of eosinophil binding at the endothelial surface [43]. Herein, the effect of incubation on cytokine-treated endothelial cells was not evaluated, but it was shown that migration of eosinophils through IL-1 $\beta$ - or IL-4-treated endothelial cells further increased $\mathrm{LTC}_{4}$ release. It is likely that part of this increase is mediated via upregulation of adhesion molecule expression on endothelial cells $[30,31]$. The inhibitory effect of endothelial cell pretreatment with IFN- $\gamma$ is important (fig. 5) and could also 
be mediated via modulation of adhesion molecule expression on endothelial cells. Moreover, the amount of $\mathrm{LTC}_{4}$ produced by eosinophils in vivo depends on its level of activation and eosinophil exposure to cytokines and mediators [10]. Thus, during migration, exposure to cytokine(s)/mediator(s) expressed by endothelial cells might be involved in the modulation of $\mathrm{LTC}_{4}$ release observed after migration of eosinophils through endothelial cells. Previous reports showed that IL-1 and IL-4 increased GM-CSF production by endothelial cells, whereas IFN- $\gamma$ decreased it [44 46].

Since blood eosinophils from asthmatic subjects are activated compared to normal eosinophils [1-5], the present authors postulated that asthmatic eosinophils might respond differently to migration through an endothelial cell monolayer. However, no difference was observed between normal and asthmatic blood eosinophils for the measured parameters. This may be related to the clinical state of the patients, given that the subjects recruited in the present study had very mild asthma. Blood eosinophils from subjects with more severe asthma might respond differently to interactions with endothelial cells.

In conclusion, the present study investigated many cell surface markers and release of leukotriene $\mathrm{C}_{4}$, a potent mediator. The data suggest that, in vivo, endothelial cells modulate specific eosinophil cell-surface marker expression and function, thus modifying eosinophil phenotype, and that these effects are themselves modulated by various cytokines and, at least in part, mediated via adhesion molecules. Therefore, evaluation of the activation status of eosinophils following their passage from blood to tissue and the increase in their capacity to interact with cells and extracellular matrix components is a very important step in understanding the role of these cells in tissue homeostasis.

\footnotetext{
Acknowledgements. The authors thank L. Trépanier for evaluating and recruiting the volunteers and J. Milot and F. Deschenes for blood sampling.
}

\section{References}

1. Weller PF, Lim K, Wan HC, et al. Role of the eosinophil in allergic reactions. Eur Respir J 1996; 9: 9-15.

2. Djukanovic R, Wilson JW, Britten KM, et al. Quantitation of mast cells and eosinophils in the bronchial mucosa of symptomatic atopic asthmatics and healthy control subjects using immunohistochemistry. Am Rev Respir Dis 1990; 142: 863-871.

3. Bousquet J, Chanez P, Lacoste JY, et al. Eosinophilic inflammation in asthma. N Engl J Med 1990; 323: 10331039.

4. Wardlaw AJ, Dunette S, Gleich GL, Collins JV, Kay AB. Eosinophils and mast cells in bronchoalveolar lavage in subjects with mild asthma: relationship to bronchial hyperreactivity. Am Rev Respir Dis 1988; 137: 62-69.

5. Mawhorter SD, Stephany DA, Ottesen EA, Nutman TB. Identification of surface molecules associated with physiologic activation of eosinophils. Application of whole-blood flow cytometry to eosinophils. J Immunol 1996; 156: 48-51.

6. Hansel TT, Braunstein JB, Walker C, et al. Sputum eosinophils from asthmatics express ICAM-1 and HLADR. Clin Exp Immunol 1991; 86: 271-277.

7. Beninati W, Derdak S, Dixon PF, et al. Pulmonary eosinophils express HLA-DR in chronic eosinophilic pneumonia. J Allergy Clin Immunol 1993; 92: 442-449.

8. Nishikawa K, Morii T, Ako H, Hamada K, Saito S, Narita N. In vivo expression of CD69 on lung eosinophils in eosinophilic pneumonia: CD69 as a possible activation marker for eosinophils. J Allergy Clin Immunol 1992; 90: 169-174.
9. Hartnell A, Robinson DS, Kay AB, Wardlaw AJ. CD69 is expressed by human eosinophils activated in vivo in asthma and in vitro by cytokines. Immunology 1993; 80: 281-286.

10. Hodges MK, Weller PF, Gerard NP, Ackerman SJ, Drazen JM. Heterogeneity of leukotriene $\mathrm{C}_{4}$ production by eosinophils from asthmatic and from normal subjects. $\mathrm{Am}$ Rev Respir Dis 1988; 138: 799-804.

11. Bass DA, Grover WH, Lewis JC, Szedja P, DeChatelet LR, McCall CE. Comparison of human eosinophils from normals and patients with eosinophilia. J Clin Invest 1980; 66: 1265-1273.

12. Sedgwick JB, Calhoun WJ, Vrtis RF, Bates MB, McAllister PK, Busse WW. Comparison of airway and blood eosinophil function after in vivo antigen challenge. J Immunol 1992; 149: $3710-3718$.

13. Georas SN, Liu MC, Newman W, Beall LD, Stealy BA, Bochner BS. Altered adhesion molecule expression and endothelial cell activation accompany the recruitment of human granulocytes to the lung after segmental antigen challenge. Am J Respir Cell Mol Biol 1992; 7: 261-269.

14. Sedgwick JB, Quan SF, Calhoun WJ, Busse WW. Effect of interleukin-5 and granulocyte-macrophage colony stimulating factor on in vitro eosinophil function: comparison with airway eosinophils. J Allergy Clin Immunol 1995; 96: 375385.

15. Bianchi E, Bender JR, Blasi F, Pardi R. Through and beyond the wall: late steps in leukocyte transendothelial migration. Immunol Today 1997; 18: 586-591.

16. Yamamoto H, Sedgwick JB, Vrtis RF, Busse WW. The effect of transendothelial migration on eosinophil function. $\mathrm{Am}$ J Respir Cell Mol Biol 2000; 23: 379-388.

17. Bochner BS, Lamas AM, Benenati SV, Schleimer RP. On the central role of vascular endothelium in allergic reaction. In: Dorsch W, ed. Late Phase Allergic Reactions. Boca Raton, CRC Press, 1990; pp. 221-235.

18. Dobrina A, Menegazzi R, Carlos TM, et al. Mechanisms of eosinophil adherence to cultured vascular endothelial cells. Eosinophils bind to the cytokine-induced ligand vascular cell adhesion molecule-1 via the very late activation antigen-4 integrin receptor. J Clin Invest 1991; 88: 20-26.

19. Ebisawa M, Bochner BS, Georas SN, Schleimer RP. Eosinophil transendothelial migration induced by cytokines. I. Role of endothelial and eosinophil adhesion molecules in IL-1 $\beta$-induced transendothelial migration. J Immunol 1992; 149: 4021-4028.

20. Moser R, Fehr J, Olgiati L, Bruijnzeel PLB. Migration of primed eosinophils across cytokine-activated endothelial cell monolayers. Blood 1992; 79: 2937-2945.

21. American Thoracic Society. Standards for the diagnosis and care of patients with chronic obstructive pulmonary disease (COPD) and asthma. Am Rev Respir Dis 1987; 136: 225-244.

22. Guilbert M, Ferland C, Bossé M, Flamand N, Lavigne S, Laviolette M. 5-Oxо-6, 8, 11, 14-eicosatetraenoic acid induces important eosinophil transmigration through basement membrane components: comparison of eosinophils from normal and asthmatic subjects. Am J Respir Cell Mol Biol 1999; 21: 97-104.

23. Taooka Y, Chen J, Yednock T, Sheppard D. The integrin $\alpha_{1} \beta_{9}$ mediates adhesion to activated endothelial cells and transendothelial neutrophil migration through interaction with vascular cell adhesion molecule-1. J Cell Biol 1999; 145: 413-420.

24. Denton MD, Geehan CS, Alexander SI, Sayegh MH, Briscoe DM. Endothelial cells modify the costimulatory capacity of transmigrating leucocytes and promotes CD28mediated $\mathrm{CD}^{+}{ }^{+} \mathrm{T}$ cell alloactivation. J Exp Med 1999; 190: 555-566.

25. Shinkai A, Yoshisue H, Koike M, et al. A novel human CC chemokine, eotaxin-3, which is expressed in IL-4-stimulated vascular endothelial cells, exhibits potent activity toward eosinophils. J Immunol 1999; 163: 1602-1610.

26. Yamamoto H, Sedgwick JB, Busse WW. Differential 
regulation of eosinophil adhesion and transmigration by pulmonary microvascular endothelial cells. J Immunol 1998; 161: 971-977.

27. Walker C, Rihs S, Braun RK, Betz S, Bruijnzeel PLB. Increased expression of $\mathrm{CD} 11 \mathrm{~b}$ and functional changes in eosinophils after migration across endothelial cell monolayers. J Immunol 1993; 150: 4061-4071.

28. Lavigne S, Bossé M, Boulet L-P, Laviolette M. Identification and analysis of eosinophils by flow cytometry using the depolarized side scatter-saponin method. Cytometry 1997; 29: 197-203.

29. Dallaire M-J, Ferland C, Lavigne S, Chakir J, Laviolette M. Migration through basement membrane modulates eosinophil expression of CD44. Clin Exp Allergy 2002; 32: 898-905.

30. Thornhill MH, Kyan-Aung U, Haskard DO. IL-4 increases human endothelial cell adhesiveness for $\mathrm{T}$ cells but not neutrophils. J Immmunol 1990; 144: 3060-3065.

31. Walsh GM. Human eosinophils: their accumulation, activation and fate. Br J Haematol 1997; 97: 701-709.

32. Powell WS, Chung D, Gravel S. 5-Oxo-6, 8, 11, 14eicosatetraenoic acid is a potent stimulator of human eosinophil migration. J Immunol 1995; 154: 4123-4132.

33. Wegner CD, Gundel RH, Reilly P, Haynes N, Letts LG, Rothlein R. Intercellular adhesion molecule-1 (ICAM-1) in the pathogenesis of asthma. Science 1990; 247: 456-459.

34. Matsumoto K, Appiah-Pippim J, Schleimer RP, Bicket CA, Beck LA, Bochner BS. CD44 and CD69 represent different types of cell-surface activation markers for human eosinophils. Am J Respir Cell Mol Biol 1998; 18: 860-866.

35. Walsh GM, Williamson ML, Symon FA, Willars GB, Wardlaw AJ. Ligation of CD69 induces apoptosis and cell death in human eosinophils cultured with granulocytemacrophage colony-stimulating factor. Blood 1996; 87: 2815-2821.

36. Testi R, Pulcinelli F, Frati L, Gazzaniga PP, Santoni A. CD69 is expressed on platelets and mediates platelet activation and aggregation. J Exp Med 1990; 172: 701707.

37. De Maria $\mathrm{R}$, Cifone MG, Trotta $\mathrm{R}$, et al. Triggering of human monocyte activation through CD69, a member of the natural killer cell gene complex family of signal transducing receptors. J Exp Med 1994; 180: 1999-2004.

38. Luttmann W, Matthiesen T, Mathys H, Virchow JC Jr. Synergistic effects of interleukin-4 or interleukin-13 and tumor necrosis factor on eosinophil activation in vitro. Am J Respir Cell Mol Biol 1999; 20: 474 480.

39. Ishihara $\mathrm{C}$, Ochiai $\mathrm{K}$, Takashahi $\mathrm{M}$, et al. Human peripheral eosinophils express functional interferon-gamma receptors (IFN- $\gamma$ R). Clin Exp Immunol 1997; 110: 524-529.

40. Luttmann W, Knoechel B, Foerster M, Matthys H, Virchow JC Jr, Kroegel C. Activation of human eosinophils by IL-13. Induction of CD69 surface antigen, its relationship to messenger RNA expression, and promotion of cellular viability. J Immunol 1996; 157: 1678-1683.

41. Berends C, Hoekstra MO, Dijkhuizen B, de Monchy JG, Gerritsen J, Kauffman HF. Expression of CD35 (CR1) and CD11b (CR3) on circulating neutrophils and eosinophils from allergic asthmatic children. Clin Exp Allergy 1993; 23: 926-933.

42. Kroegel C, Virchow JC Jr, Luttmann W, Walker C, Warner JA. Pulmonary immune cells in health and disease: the eosinophil leucocyte (Part I). Eur Respir J 1994; 7: 519543 .

43. Munoz MM, Hamann KJ, Rabe KF, Sano H, Zhu X, Leff AR. Augmentation of eosinophil degranulation and $\mathrm{LTC}_{4}$ secretion by integrin-mediated endothelial cell adhesion. Am J Physiol 1999; 277: 802-810.

44. Rajavashisth TB, Andalibi A, Territo MC, et al. Induction of endothelial cell expression of granulocyte and macrophage colony-stimulating factor by modified low-density lipoproteins. Nature 1990; 344: 254-257.

45. Paleolog EM, Aluri GR, Feldmann M. Contrasting effects of interferon gamma and interleukin 4 on responses of human vascular endothelial cells to tumor necrosis factor alpha. Cytokine 1992; 4: 470-478.

46. Lenhoff S, Olofsson T. Cytokine regulation of GM-CSF and G-CSF secretion by human umbilical cord vein endothelial cells (HUVEC). Cytokine 1996; 8: 702-709. 